\title{
New atpenins, NBRI23477 A and B, inhibit the growth of human prostate cancer cells
}

\author{
Manabu Kawada ${ }^{1}$, Isao Momose ${ }^{1}$, Tetsuya Someno ${ }^{1}$, Goh Tsujiuchi ${ }^{2}$ and Daishiro Ikeda ${ }^{1}$ \\ The growth and metastasis of prostate cancer are regulated by prostate stroma through the tumor-stromal cell interactions. \\ Small molecules that modulate the tumor-stromal cell interactions will be new anticancer drugs. In the course of our screening \\ of the modulators, we isolated two new atpenins, NBRI23477 A (4) and B (5), from the fermentation broth of Penicillium \\ atramentosum PF1420. Compounds 4 and 5 as well as atpenin A4 (1), A5 (2) and B (3) inhibited the growth of human prostate \\ cancer DU-145 cells in the coculture with human prostate stromal cells more strongly than that of DU-145 cells alone.
}

The Journal of Antibiotics (2009) 62, 243-246; doi:10.1038/ja.2009.20; published online 13 March 2009

Keywords: antitumor drug; atpenin; prostate cancer; prostate stroma

\section{INTRODUCTION}

The growth and metastasis of prostate cancer are regulated by prostate stroma. ${ }^{1,2}$ We have reported earlier that prostate stromal cell (PrSC) promotes the growth of human prostate cancer cells through the secretion of insulin-like growth factor-I. ${ }^{3,4}$ There is a possibility that small molecules could inhibit cancer cell growth by modulating tumor-stromal cell interactions. We developed the in vitro coculture system of human prostate cancer cells and PrSC, in which the growth of prostate cancer cell is increased by the coculture with PrSC. ${ }^{3,5}$ Using the assay method, we have been searching for the modulators of the tumor-stromal cell interactions. In the course of our screening of the modulators, we isolated new atpenins, NBRI23477 A (4) and B (5), along with the known compounds, atpenin A4 (1), A5 (2) and B (3)..$^{6,7}$ Here we describe the isolation, structure determination and biological activity of $\mathbf{4}$ and $\mathbf{5}$. We also report the activity of $\mathbf{1 , 2}$ and $\mathbf{3}$ on our assay.

\section{MATERIALS AND METHODS}

\section{Reagents}

Rhodanile blue was purchased from Aldrich (Milwaukee, WI, USA). Insulin and hydrocortisone were obtained from Sigma (St Louis, MO, USA). Transferrin was obtained from Wako Pure Chemical Industries (Tokyo, Japan). The recombinant human basic fibroblast growth factor was purchased from Pepro Tech (London, UK).

\section{Cells}

The human prostate cancer DU-145 cells were obtained from American Type Culture Collection (Manassas, VA, USA) and maintained in Dulbecco's modified Eagle's medium supplemented with $10 \%$ fetal bovine serum (ICN Biomedicals, Aurora, OH, USA), $100 \mathrm{U} \mathrm{ml}^{-1}$ penicillin $\mathrm{G}$ and $100 \mu \mathrm{g} \mathrm{ml}^{-1}$ streptomycin at $37^{\circ} \mathrm{C}$ with $5 \% \mathrm{CO}_{2}$. The human normal PrSCs were obtained from Bio Whittaker (Walkersville, MD, USA) and maintained in Dulbecco's modified Eagle's medium supplemented with $10 \%$ fetal bovine serum, $100 \mathrm{U} \mathrm{ml}^{-1}$ penicillin $\mathrm{G}, 100 \mu \mathrm{g} \mathrm{ml}^{-1}$ streptomycin, ITH $\left(5 \mu \mathrm{g} \mathrm{ml}^{-1}\right.$ insulin, $5 \mu \mathrm{g} \mathrm{ml}^{-1}$ transferrin and $1.4 \mu \mathrm{M}$ hydrocortisone) and $5 \mathrm{ng} \mathrm{ml}^{-1}$ human basic fibroblast growth factor at $37^{\circ} \mathrm{C}$ with $5 \% \mathrm{CO}_{2}$.

\section{Coculture experiment}

A microplate assay method for the selective measurement of epithelial tumor cells in coculture with stromal cells using rhodanile blue dye was performed as described before. ${ }^{5}$ PrSCs were first inoculated into 96-well plates at 5000 cells per well in $100 \mu \mathrm{l}$ of Dulbecco's modified Eagle's medium supplemented with ITH and $0.1 \%$ fetal bovine serum in the presence of various concentrations of the test compounds. After 2 days, $10 \mu \mathrm{l}$ of DU-145 cell suspension (5000 cells) in serum-free Dulbecco's modified Eagle's medium was inoculated onto a monolayer of PrSC, and the cells were further cultured for 3 days. For monoculture of DU- 145 cells, the assay medium alone was first incubated in the presence of test compounds for 2 days at $37^{\circ} \mathrm{C}$. Then, DU-145 cells were inoculated as described above and cultured for further 3 days.

\section{Analytical measurement}

Melting points were obtained on a Yanagimoto micro melting point apparatus (Yanagimoto, Kyoto, Japan). Optical rotations were measured on a JASCO P-1030 polarimeter (JASCO, Tokyo, Japan). UV spectra were recorded on a Hitachi 228 A spectrometer (Hitachi, Tokyo, Japan). ${ }^{1} \mathrm{H}$ - and ${ }^{13} \mathrm{C}-\mathrm{NMR}$ spectra were measured on a JEOL JNM A400 spectrometer (JEOL, Tokyo, Japan) using TMS as an internal standard. High resolution electrospray ionization mass spectrometry (HR-ESI-MS) spectra were measured with a JEOL JMS-T100LC spectrometer (JEOL).

\section{Fermentation of fungal strain PF1420}

Penicillium atramentosum PF1420 was isolated from a soil sample collected in Iwamizawa, Hokkaido, Japan. A slant culture of P. atramentosum PF1420 was used to inoculate 100-ml Erlenmeyer flasks. Each contained $20 \mathrm{ml}$ of a seed 
medium consisting of $2.0 \%$ soluble starch, $1.0 \%$ glucose, $0.2 \%$ soybean meal, $0.6 \%$ wheat germ, $0.5 \%$ polypeptone, $0.3 \%$ yeast extract and $0.2 \% \mathrm{CaCO}_{3}$ in deionized water adjusted to $\mathrm{pH} 7.2$ with $\mathrm{NaOH}$ solution before sterilization. The flasks were incubated at $25^{\circ} \mathrm{C}$ for $72 \mathrm{~h}$ on a rotary shaker at 220 r.p.m. Portions of $1.0 \mathrm{ml}$ of this seed culture were transferred into six $500-\mathrm{ml}$ Erlenmeyer flasks, each of which contained $100 \mathrm{ml}$ of a seed medium. The flasks were incubated at $25^{\circ} \mathrm{C}$ for $48 \mathrm{~h}$ on a rotary shaker at 220 r.p.m. Portions of $150 \mathrm{ml}$ of this seed culture were transferred into four stainless vats, each of which contained $2.5 \%$ soybean meal and water-absorbed rice $(4 \mathrm{~kg})$ as solid production medium. The stainless vats were thoroughly stirred and then statically cultured at $25^{\circ} \mathrm{C}$ for 14 days. After incubation, 16-kg portion of the obtained culture was extracted with 321 of $67 \%$ aqueous acetone.

\section{RESULTS}

Isolation procedure for atpenins

The 16-kg culture broth of $P$. atramentosum PF1420 was extracted with 321 of $67 \%$ aqueous acetone. The filtrate of the extracts was concentrated in vacuo to remove acetone. The aqueous solution (5l, $\mathrm{pH} 7$ ) was applied on an HP-20 column. After washing the column with $\mathrm{H}_{2} \mathrm{O}$ and $50 \% \mathrm{MeOH}$, active ingredients were eluted with $100 \%$ $\mathrm{MeOH}$. The eluate was concentrated in vacuo, dissolved in $600 \mathrm{ml}$ $\mathrm{H}_{2} \mathrm{O}$ and then extracted with EtOAc. The organic layer was dried over $\mathrm{Na}_{2} \mathrm{SO}_{4}$ and concentrated in vacuo to afford $9.92 \mathrm{~g}$ of dried material. The materials were applied on a silica gel column (450 g, Wakogel C-200, 75-150 $\mu \mathrm{m}$; Wako, Osaka, Japan) prepared with $\mathrm{CHCl}_{3}$, and eluted with $\mathrm{CHCl}_{3}$ and $\mathrm{CHCl}_{3}-\mathrm{MeOH}$. The fractions eluted with $\mathrm{CHCl}_{3}-\mathrm{MeOH}(25: 1)$ were concentrated in vacuo to give $4.13 \mathrm{~g}$ of viscous material. The viscous material was applied on gel filtration chromatography of Sephadex LH-20 (MeOH). The fractions containing atpenins were concentrated in vacuo to give $2.76 \mathrm{~g}$ of crude material. The crude material was purified by a reversed-phase HPLC column (Inertsil ODS-3, $20 \times 250 \mathrm{~mm}, 6.0 \mathrm{ml} \mathrm{min}^{-1}$ ) with $50 \%$ $\mathrm{CH}_{3} \mathrm{CN}$ to afford crude atpenins, $46.4 \mathrm{mg}$ of $1,119.8 \mathrm{mg}$ of 2 ,
$111.1 \mathrm{mg}$ of $\mathbf{3}$ and $\mathbf{4}$, and $14.5 \mathrm{mg}$ of $\mathbf{5}$. The crude sample of $\mathbf{5}$ was applied on a Sephadex LH-20 column $(\mathrm{MeOH})$ to afford pure $8.0 \mathrm{mg}$ of $\mathbf{5}$. The crude mixture of $\mathbf{3}$ and $\mathbf{4}$ was further purified by a reversed-

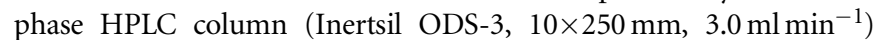
with $75 \% \mathrm{CH}_{3} \mathrm{CN}$ and $0.1 \% \mathrm{TFA}$, and then the fractions containing

Table 2 The ${ }^{13} \mathrm{C}$ - and ${ }^{1} \mathrm{H}$-NMR assignments of 4 and 5 in pyridine- $d_{5}$

\begin{tabular}{|c|c|c|c|c|}
\hline \multirow[b]{2}{*}{ Position } & \multicolumn{2}{|r|}{4} & \multicolumn{2}{|r|}{5} \\
\hline & $\begin{array}{c}{ }^{13} \text { C p.p.m. } \\
\text { (mult.) }\end{array}$ & $\begin{array}{l}{ }^{1} \mathrm{H} \text { p.p.m. } \\
\text { (mult., } J(H z))\end{array}$ & $\begin{array}{c}{ }^{13} \text { C p.p.m. } \\
\text { (mult.) }\end{array}$ & $\begin{array}{l}{ }^{1} \mathrm{H} \text { p.p.m. } \\
\text { (mult., } J(\mathrm{~Hz}) \text { ) }\end{array}$ \\
\hline $2^{a}$ & $162.7(\mathrm{~s})$ & & $162.8(\mathrm{~s})$ & \\
\hline 3 & $100.6(\mathrm{~s})$ & & $101.0(\mathrm{~s})$ & \\
\hline $4^{\mathrm{a}}$ & $165.9(\mathrm{~s})$ & & $165.8(\mathrm{~s})$ & \\
\hline 5 & $125.0(\mathrm{~s})$ & & 124.9 (s) & \\
\hline $5-\mathrm{OCH}_{3}$ & $60.7(q)$ & $3.84(\mathrm{~s})$ & $60.7(q)$ & $3.83(\mathrm{~s})$ \\
\hline 6 & $160.2(\mathrm{~s})$ & & $160.1(\mathrm{~s})$ & \\
\hline $6-\mathrm{OCH}_{3}$ & $54.4(q)$ & $3.90(\mathrm{~s})$ & $54.4(q)$ & $3.89(\mathrm{~s})$ \\
\hline $1^{\prime}$ & $210.6(s)$ & & $211.3(\mathrm{~s})$ & \\
\hline $2^{\prime}$ & $42.2(d)$ & $4.36(\mathrm{~m})$ & $42.2(d)$ & $4.42(\mathrm{~m})$ \\
\hline $2^{\prime}-\mathrm{CH}_{3}$ & $16.4(q)$ & $1.35(\mathrm{~d}, 6.4)$ & $18.1(q)$ & $1.33(\mathrm{~d}, 6.8)$ \\
\hline $3^{\prime}$ & $36.8(t)$ & $2.06-2.13(\mathrm{~m})$ & $41.0(\mathrm{t})$ & $\begin{array}{l}1.42(\mathrm{~m}) \\
2.10(\mathrm{~m})\end{array}$ \\
\hline $4^{\prime}$ & $48.0(d)$ & $2.40(\mathrm{~m})$ & $36.6(d)$ & $2.33(\mathrm{~m})$ \\
\hline $4^{\prime}-\mathrm{CH}_{3}$ & $15.8(q)$ & $1.34(\mathrm{~d}, 6.4)$ & $20.5(q)$ & $1.07(\mathrm{~d}, 6.8)$ \\
\hline $5^{\prime}$ & 97.9 (s) & & 145.2 (d) & $5.79(\mathrm{ddd}, 7.6,10.4,17.2)$ \\
\hline $6^{\prime}$ & $35.7(q)$ & $2.14(\mathrm{~s})$ & $114.4(\mathrm{t})$ & $\begin{array}{l}4.95(\mathrm{dd}, 1.2,10.4) \\
4.99(\mathrm{dd}, 1.2,17.2)\end{array}$ \\
\hline
\end{tabular}

aAssignments may be interchanged

Chemical shifts in p.p.m. from TMS as an internal standard.

The ${ }^{13} \mathrm{C}$ - and ${ }^{1} \mathrm{H}$-NMR were measured at 100 and $400 \mathrm{MHz}$, respectively.
Table 1 Physicochemical properties of 4 and 5

\begin{tabular}{|c|c|c|}
\hline & 4 & 5 \\
\hline Appearance & White powder & Hygroscopic solid \\
\hline Melting point & $130-132{ }^{\circ} \mathrm{C}$ & - \\
\hline Molecular formula & $\mathrm{C}_{15} \mathrm{H}_{21} \mathrm{NO}_{5} \mathrm{Cl}_{2}$ & $\mathrm{C}_{15} \mathrm{H}_{21} \mathrm{NO}_{5}$ \\
\hline \multicolumn{3}{|l|}{$H R-E S I-M S(m / z)$} \\
\hline Found & $364.0713(\mathrm{M}-\mathrm{H})^{-}$ & $294.1361(\mathrm{M}-\mathrm{H})^{-}$ \\
\hline Calcd. & 364.0719 for $\mathrm{C}_{15} \mathrm{H}_{20} \mathrm{NO}_{5} \mathrm{Cl}_{2}$ & 294.1342 for $\mathrm{C}_{15} \mathrm{H}_{20} \mathrm{NO}_{5}$ \\
\hline$U V \lambda_{\max }(\mathrm{nm})(\mathrm{MeOH})$ & $236,273,329$ & $235,271,331$ \\
\hline$[\alpha]_{D}^{20}(c 0.2, E t O H)$ & $-37^{\circ}$ & $-39^{\circ}$ \\
\hline $\mathrm{IR} v_{\max }(\mathrm{KBr})\left(\mathrm{cm}^{-1}\right)$ & $\begin{array}{l}2935,1651,1597,1448 \\
1325,1198,1163,995\end{array}$ & $\begin{array}{l}2931,1651,1597,1452 \\
1325,1196,1163,995\end{array}$ \\
\hline
\end{tabular}

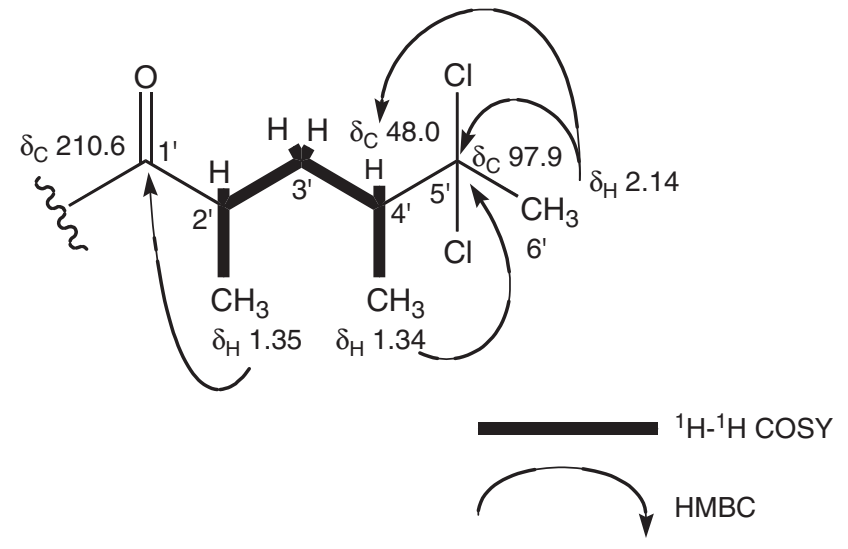

Figure 2 Partial structure of 4.<smiles>[R]CC([R8])[C@@H](C)C[C@@H](C)C(=O)c1c(O)[14c](OC)c(OC)[n+](C)c1O</smiles>

Atpenin A4 (1): $\mathrm{R}_{1}=\mathrm{Cl}, \mathrm{R}_{2}=\mathrm{H}$

Atpenin $\mathrm{A} 5$ (2): $\mathrm{R}_{1}=\mathrm{Cl}, \mathrm{R}_{2}=\mathrm{Cl}$

Atpenin $B$ (3): $\mathrm{R}_{1}=\mathrm{H}, \mathrm{R}_{2}=\mathrm{H}$<smiles>COc1nc(O)c(C(=O)C(C)CC(C)C(C)(Cl)Cl)c(O)c1OC</smiles>

NBRI23477 A (4)<smiles>C=CC(C)CC(C)C(=O)c1c(O)nc(OC)c(OC)c1O</smiles>

NBRI23477 B (5)

Figure 1 Structures of $\mathbf{1 - 5}$. 
3 and 4 were applied on a Sephadex LH-20 column (MeOH) to afford pure $72.4 \mathrm{mg}$ of 3 and $4.5 \mathrm{mg}$ of 4 , respectively. The crude mixture of 1 and 2 was further purified by a reversed-phase HPLC column (Inertsil ODS-3, $10 \times 250 \mathrm{~mm}, 3.0 \mathrm{ml} \mathrm{min}^{-1}$ ) with $60 \% \mathrm{CH}_{3} \mathrm{CN}$ and $0.1 \%$ TFA, and then the fractions containing $\mathbf{1}$ and $\mathbf{2}$ were applied on a Sephadex LH-20 column (MeOH) to afford pure $15.5 \mathrm{mg}$ of 1 and $26.1 \mathrm{mg}$ of $\mathbf{2}$, respectively. Separation by analytical HPLC (Inertsil ODS-3, $3 \mu \mathrm{m}$, $4.6 \times 150 \mathrm{~mm}, 1.0 \mathrm{ml} \mathrm{min}^{-1}$ ) with $75 \% \mathrm{CH}_{3} \mathrm{CN}$ and $0.1 \%$ TFA gave the following retention times (in minutes): 4.38 (1), 4.40 (2), 5.29 (3), 4.95 (4) and 4.28 (5).

\section{Physicochemical properties}

The physicochemical properties of $\mathbf{4}$ and $\mathbf{5}$ are summarized in Table 1. They are soluble in $\mathrm{MeOH}$ and DMSO. The molecular formulae of 4 and 5 were determined to be $\mathrm{C}_{15} \mathrm{H}_{21} \mathrm{NO}_{5} \mathrm{Cl}_{2}$ and $\mathrm{C}_{15} \mathrm{H}_{21} \mathrm{NO}_{5}$, respectively, by HR-ESI-MS. The general features of their UV and NMR spectra resembled each other, indicating structural similarities of these compounds. Compounds 1-3 were identified by NMR spectra as atpenin A4 (1), A5 (2) and B (3), respectively (Figure 1). 6,7

Structure determination of NBRI23477 A (4)

The ${ }^{1} \mathrm{H}$ - and ${ }^{13} \mathrm{C}$-NMR data of 4 (Table 2) were similar to those of $2 .{ }^{8}$ However, the signals of $5^{\prime}$-methine and $6^{\prime}$-methylene of 2 were not observed in the ${ }^{13} \mathrm{C}$-NMR spectrum of 4 , but a quaternary carbon $(\delta$ 97.9) and a methyl carbon $(\delta$ 35.7) appeared in 4 . The partial structure of 4 was established by analyses of ${ }^{1} \mathrm{H}_{-}{ }^{1} \mathrm{H}$ correlation spectroscopy (COSY) and heteronuclear multiple bond connectivity (HMBC) spectra (Figure 2). ${ }^{1} \mathrm{H}_{-}{ }^{1} \mathrm{H}$ COSY spectrum revealed the following fragment: $-\mathrm{CH}\left(\mathrm{CH}_{3}\right)-\mathrm{CH}_{2}-\mathrm{CH}\left(\mathrm{CH}_{3}\right)$-. In the HMBC spectrum, singlet methyl protons $\left(6^{\prime}-\mathrm{H}, \delta\right.$ 2.14) correlated to a quaternary carbon $\left(\mathrm{C}-5^{\prime}, \delta 97.9\right)$ and a methine carbon $\left(\mathrm{C}-4^{\prime}, \delta 48.0\right)$. Methyl protons $(\delta 1.35)$ connecting to $\mathrm{C}-2^{\prime}$ methine correlated to a carbonyl carbon $\left(\mathrm{C}-1^{\prime}, \delta 210.6\right)$. Therefore, the total structure of 4 was found to be a new family of atpenin (Figure 1).

\section{Structure determination of NBRI23477 B (5)}

The ${ }^{13} \mathrm{C}$ - and ${ }^{1} \mathrm{H}-\mathrm{NMR}$ data of $\mathbf{5}$ (Table 2) were similar to those of 3. ${ }^{6,7}$ However, the signals of $5^{\prime}$-methylene and $6^{\prime}$-methyl of 3 were not observed in the ${ }^{13} \mathrm{C}-\mathrm{NMR}$ spectrum of 5 . On the other hand, an olefine carbon $(\delta$ 145.2) and a terminal olefine carbon $(\delta 114.4)$ were observed in $\mathbf{5}$. The partial structure of $\mathbf{5}$ was established by analyses of the ${ }^{1} \mathrm{H}_{-}{ }^{1} \mathrm{H}$ COSY and $\mathrm{HMBC}$ spectra (Figure 3). ${ }^{1} \mathrm{H}-{ }^{1} \mathrm{H}$ COSY

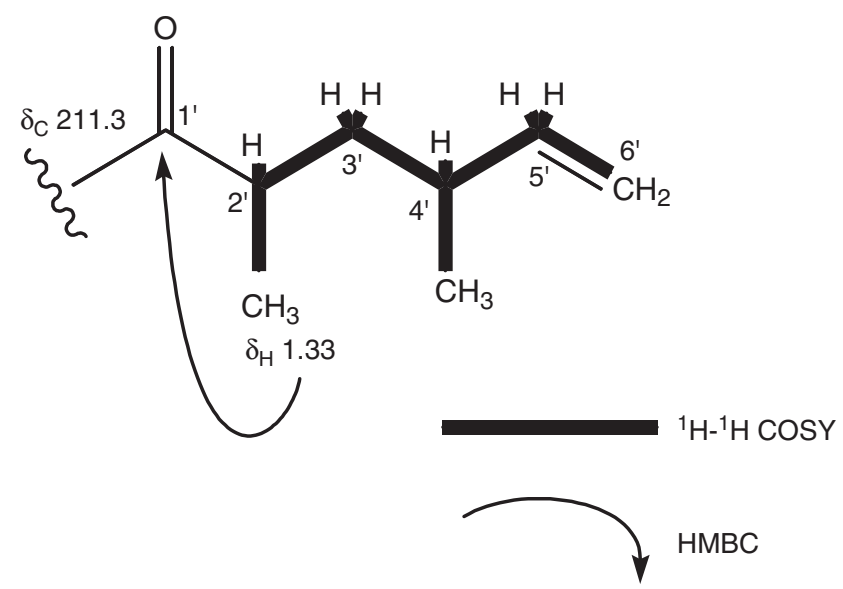

Figure 3 Partial structure of 5.
Compound 1

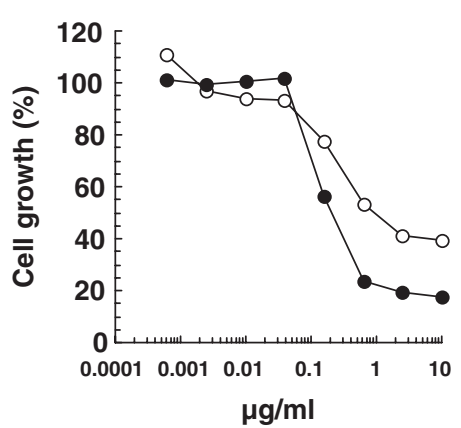

Compound 4

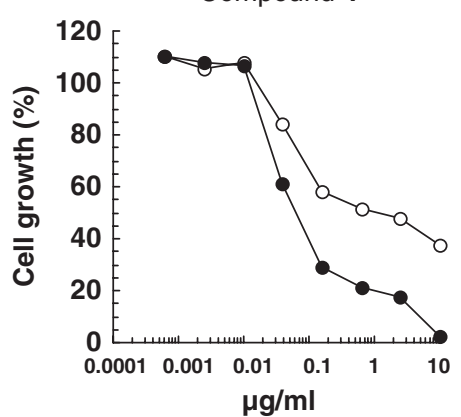

Compound 2

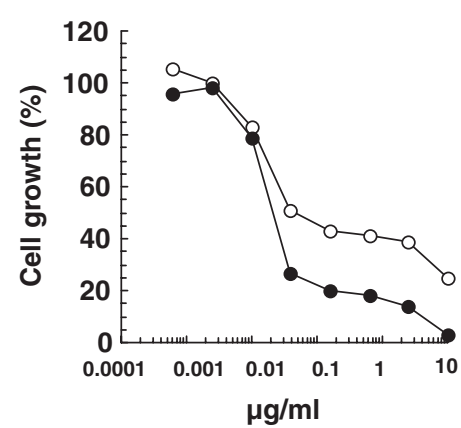

Compound 5

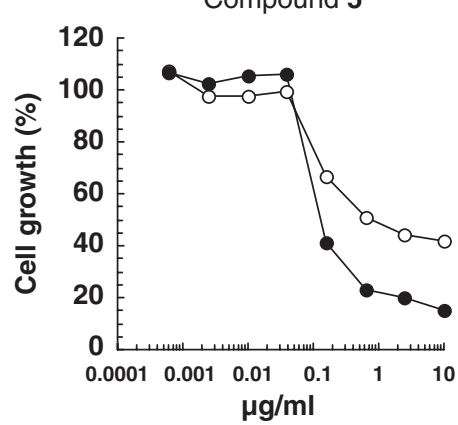

Compound 3

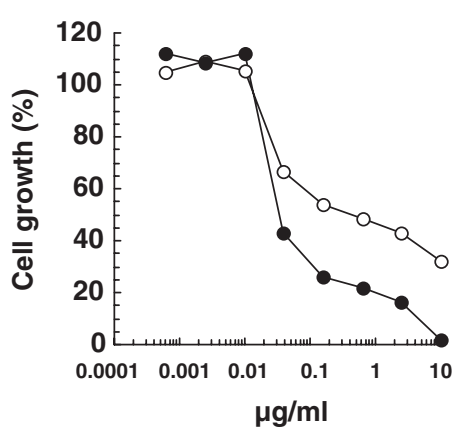

Figure 4 Effects of $\mathbf{1 - 5}$ on coculture of DU-145 cells and PrSC. The growth of DU-145 cells cocultured with PrSC $(\bullet)$ or that of DU-145 cells alone $(O)$ in the presence of the indicated concentrations of 1-5 was determined using rhodanile blue method. Values are means of duplicate determinations. Each s.e. is less than $10 \%$. 
spectrum revealed the following fragment: $-\mathrm{CH}\left(\mathrm{CH}_{3}\right)-\mathrm{CH}_{2}$ $\mathrm{CH}\left(\mathrm{CH}_{3}\right)-\mathrm{CH}=\mathrm{CH}_{2}$. In the $\mathrm{HMBC}$ spectrum, a methyl proton $(\delta$ 1.33) connecting to C-2' methine correlated to a carbonyl carbon $\left(\mathrm{C}-1^{\prime}, \delta 211.3\right)$. Therefore, the total structure of $\mathbf{5}$ was found to be a new family of atpenin (Figure 1).

\section{Biological activities}

The effects of 1-5 on coculture of human prostate cancer DU-145 cells with PrSC were determined using rhodanile blue staining method. ${ }^{5}$ In the coculture, the growth of DU-145 cells is increased by PrSC. ${ }^{3,5}$ As shown in Figure 4, all compounds showed selective growth inhibitory activities and inhibited the growth of DU-145 cells in coculture with PrSC more strongly than that of DU-145 cells alone. The $\mathrm{IC}_{50}$ values of 1-5 against the growth of DU-145 cells in coculture were 0.21 , $0.021,0.034,0.064$ and $0.13 \mu \mathrm{g} \mathrm{ml}^{-1}$, respectively, whereas those of $\mathbf{1 - 5}$ against the growth of DU-145 cells alone were 0.85, 0.048, 0.54, 0.95 and $0.71 \mu \mathrm{g} \mathrm{ml}^{-1}$, respectively. All compounds did not show apparent cytotoxicity against stromal cells under microscopic observation (data not shown).

\section{DISCUSSION}

In this study, we have also obtained three structurally related compounds in addition to $\mathbf{1 - 5}$. The HR-ESI-MS spectra revealed that the molecular formulae of these compounds were $\mathrm{C}_{15} \mathrm{H}_{22} \mathrm{NO}_{6} \mathrm{Cl}$, $\mathrm{C}_{15} \mathrm{H}_{23} \mathrm{NO}_{6}$ and $\mathrm{C}_{15} \mathrm{H}_{20} \mathrm{NO}_{5} \mathrm{Cl}_{3}$, respectively. Among them, a compound having the molecular formula of $\mathrm{C}_{15} \mathrm{H}_{20} \mathrm{NO}_{5} \mathrm{Cl}_{3}$ may be identical to reported WF-16775 A2, ${ }^{8}$ but we could not elucidate the structures of additional three compounds further due to their trace amounts. Ōmura et al. ${ }^{6}$ reported that there were atpenins A1, A2 and $\mathrm{A} 3$ along with $\mathrm{A} 4, \mathrm{~A} 5$ and $\mathrm{B}$, but they did not obtain $\mathrm{A} 1, \mathrm{~A} 2$ and $\mathrm{A} 3$ in pure form and did not show any structural information. We cannot exclude the possibility that $\mathbf{4}$ and $\mathbf{5}$ would be identical to one of them. However, we have actually presented here two new structures of atpenins.

Atpenins A4, A5 and B were originally isolated as antifungal antibiotics. ${ }^{6,7}$ Thereafter, atpenin B was found to decrease the cellular adenosine $5^{\prime}$-triphosphate. ${ }^{9}$ Furthermore, it is reported that atpenins specifically inhibit mitochondrial complex II (succinate-ubiquinone oxidoreductase).${ }^{10}$ Mitochondria is now considered as a rational target for cancer therapy. ${ }^{11}$ Although there is a possibility that atpenins modulate tumor-stromal cell interactions by inhibiting mitochondrial functions, the elucidation of the precise mechanism of action needs to be studied further. We are now studying the effects of atpenins on tumor growth in vivo using mouse xenograft models.

\section{ACKNOWLEDGEMENTS}

We thank Dr R Sawa (Microbial Chemistry Research Center) for analysis of HR-ESI-MS spectra, and Ms K Adachi and Ms E Satoh for their technical assistance. This work was supported in part by a grant-in-aid from the Ministry of Education, Culture, Sports, Science and Technology of Japan.

1 Grossfeld, G. D., Hayward, S. W., Tlsty, T. D. \& Cunha, G. R. The role of stroma in prostatic carcinogenesis. Endocr. Relat. Cancer 5, 253-270 (1998).

2 Tuxhorn, J. A., Ayala, G. E. \& Rowley, D. R. Reactive stroma in prostate cancer progression. J. Urol. 166, 2472-2483 (2001).

3 Kawada, M., Inoue, H., Masuda, T. \& Ikeda, D. Insulin-like growth factor I secreted from prostate stromal cells mediates tumor-stromal cell interactions of prostate cancer. Cancer Res. 66, 4419-4425 (2006).

4 Kawada, M., Inoue, H., Arakawa, M. \& Ikeda, D. Transforming growth factor- $\beta 1$ modulates tumor-stromal cell interactions of prostate cancer through insulin-like growth factor-I. Anticancer Res. 28, 721-730 (2008).

5 Kawada, M. et al. A microplate assay for selective measurement of growth of epithelial tumor cells in direct coculture with stromal cells. Anticancer Res. 24, 1561-1568 (2004).

6 Ōmura, S. et al. Atpenins, new antifungal antibiotics produced by Penicillium sp. Production, isolation, physico-chemical and biological properties. J. Antibiot. 41, 1769-1773 (1988).

7 Kumagai, H., Nishida, H., Imamura, N., Tomoda, H. \& Ōmura, S. Structures of atpenins A4, A5 and B, new antifungal antibiotics produced by Penicillium sp. J. Antibiot. 43, 1553-1558 (1990).

8 Otsuka, T., Takase, S., Terano, H. \& Okuhara, M. New angiogenesis inhibitors, WF-16755A1 and A2. J. Antibiot. 45, 1970-1973 (1992).

9 Oshino, K., Kumagai, H., Tomoda, H. \& Ōmura, S. Mechanism of action of atpenin B on Raji cells. J. Antibiot. 43, 1064-1068 (1990).

10 Miyadera, H. et al. Atpenins, potent and specific inhibitors of mitochondrial complex II (succinate-ubiquinone oxidoreductase). Proc. Natl Acad. Sci. USA 100, 473-477 (2003).

11 Kim, J. \& Dang, C. Cancer's molecular sweet tooth and the Warburg effect. Cancer Res. $66,8927-8930$ (2006). 